\title{
Application of the Air Quality Forecasting Analysis Using NARX Models
}

\author{
NARX Modellerini Kullanarak Hava Kalitesi Tahmin Analizinin Uygulanması
}

\author{
Yelda FIRAT* \\ Çanakkale Onsekiz Mart University, Çanakkale Vocational School of Technical Sciences, Department of Computer Technologies, \\ 17100, Çanakkale, Turkey
}

• Geliş tarihi / Received: 16.08.2019 • Düzeltilerek geliş tarihi / Received in revised form: $21.02 .2020 \quad$ • Kabul tarihi / Accepted: 29.02 .2020

\begin{abstract}
Air quality management and forecasting play a crucially important role in environmental problems. It is known that air quality problem is directly related to the quality of life and human health. In order to solve this problem, there are some conventional forecasting methods used in the literature. This paper presents a new non-linear autoregressive exogenous model method. In this method, all air quality parameters are entered into the system for four different locations. These are Çanakkale Central and the districts of Çan, Lapseki and Biga. This created model provides obtaining and extracting of some unmeasured environmental pollutant parameters for other air quality stations such as Nitric oxide (NO), Nitrogen oxide $\left(\mathrm{NO}_{2}\right)$, Nitrogen oxides $\left(\mathrm{NO}_{\mathrm{X}}\right)$ and Ozone $\left(\mathrm{O}_{3}\right)$. Within these stations, the Çanakkale Central air quality monitoring station measures only Particulate matter $\left(\mathrm{PM}_{10}\right)$ and Sulfur dioxide $\left(\mathrm{SO}_{2}\right)$ parameters while others measure the parameters of $\mathrm{PM}_{10}, \mathrm{PM}_{2.5}, \mathrm{SO}_{2}, \mathrm{NO}, \mathrm{NO}_{2}, \mathrm{NO}_{\mathrm{X}}$ and $\mathrm{O}_{3}$. Presented numerical model results are verified with measurement results and extracted acceleration error. These numerical results are realized for Çanakkale Central. Obtained results show that the forecasted parameter values are very successful and error acceleration is very low. The success of the learning process is over $90 \%$.
\end{abstract}

Keywords: Air Quality, Çanakkale, Forecasting, NARX

\section{$\ddot{\boldsymbol{O}} z$}

Hava kalite yönetimi ve tahmini çevre sorunlarında hayati derecede önemli bir rol oynamaktadır. Hava kalitesi sorununun insan sağliğl ve yaşam kalitesi ile doğrudan ilişkili olduğu bilinmektedir. Bu sorunu çözmek için, literatürde kullanılan bazı alışılagelmiş metotlar bulunmaktadır. Bu çalışma yeni doğrusal olmayan özbağlanımlı dışsal model yöntemini işlemektedir. Bu yöntemde tüm hava kalitesi parametreleri dört farklı yer bakımından sisteme girilmektedir. Bunlar Çanakkale Merkez ve Çan, Lapseki ve Biga ilçeleridir. Oluşturulan bu model, hava kalite istasyonları için Nitrik oksit (NO), Nitrojen oksit $\left(\mathrm{NO}_{2}\right)$, Nitrojen oksitler $\left(\mathrm{NO}_{X}\right)$ ve Ozon $\left(\mathrm{O}_{3}\right)$ gibi bazl ölçülmeyen çevresel kirletici parametrelerin elde edilmesi ve ayıklanmasını sağlamaktadır. Bu istasyonlarda, Çanakkale Merkez hava kalitesi izleme istasyonu sadece Partikül madde (PM $\left.M_{10}\right)$ ve Sülfür dioksit $\left(\mathrm{SO}_{2}\right)$ parametrelerini ölçerken, diğerleri $\mathrm{PM}_{10}, \mathrm{PM}_{2.5}, \mathrm{SO}_{2}$, $\mathrm{NO}, \mathrm{NO}_{2}, \mathrm{NO}_{X}$ ve $\mathrm{O}_{3}$ parametrelerini ölçmektedir. Sunulan sayısal yöntem sonuçları, ölçüm sonuçları ve çıkarılan ivme hatası ile doğrulanmaktadır. Bu sayısal sonuçlar Çanakkale Merkez için dikkate alınmaktadır. Elde edilen sonuçlar, öngörülen parametre değerlerinin çok başarılı olduğunu ve hata ivmesinin çok düşük olduğunu göstermektedir. Öğrenme sürecinin başarısı \%90'nın üzerindedir.

Anahtar kelimeler: Hava Kalitesi, Çanakkale, Hava Tahmini, NARX

\footnotetext{
* Yelda FIRAT; yfirat@comu.edu.tr, Tel: (0505) 38655 14, orcid.org/0000-0002-6741-2507
} 


\section{Introduction}

Air pollution and quality play a crucial role in various countries around the world and cause enormous environmental problems. The development of technology, increased population and industrialized areas provide rapid economic development. In this study, Çanakkale city, located on both sides of the Dardanelles Strait directly connecting the Sea of Marmara with the Aegean Sea, has been selected as a study area.

On the other hand, the air pollution level is very serious and mainly reflected as a high concentration of suspended pollutant parameters in the city air environment within Çanakkale. In recent years, air pollution has led to a progressive climate change in Çanakkale and other cities (URL-3, 2019).

In order to prevent the negative effects of environmental pollution on global warming and human health, Çanakkale and many other cities have been trying to prevent air pollution through action plans according to the air quality estimates (Kurt and Oktay, 2010; Ortiz-Garcia et al., 2010; Wang et al., 2017; Zhu et al., 2017).

High level of air pollution gives rise to human health problems. Air pollution consists of many gas air pollutants such as $\mathrm{PM}_{10}, \mathrm{SO}_{2}, \mathrm{NO}, \mathrm{NO}_{2}$, $\mathrm{CO}$ and etc. These pollutants directly affect respiration and food quality. According to the food security studies (URL-1, 2018), increasing ozone precursor emissions was forecasted to cause relative worldwide crop losses for wheat 7-12\%, soy $6-16 \%$ and maize $3-5 \%$. Also, another recognized paper presents the economic losses due to the effect of ozone on 23 crops as amounted to 6.7 billion Euros at the European level for one year (Wilkinson et al., 2012). There are many studies on food quality (Khalid et al., 2017; Mickelson and Tsvankin, 2017; Sun et al., 2017; Fathy El-Sharkawy and Javed, 2018) and air pollution (Sheppard et al., 2010; Hristov, 2011; Hamaoui et al., 2014; Sun et al., 2017). The primary ecological concern with ammonia emissions is the formation of particles as a result of atmospheric reactions. Air particles of ammonia emissions, mainly from fertilized land and animal waste, are presently responsible for $75 \%$ of global emissions (Hung et al., 2018; Zheng et al., 2018).

Additionally, the literature on air quality and pollution were cited. Jaikumar et al. (2018) meteorological and traffic parameters near busy urban corridors were used to train NARX based neural network model for the prediction of ambient air quality. Diagnostic analysis between different model variables was done to understand the relationship between one other. The developed model predicted $\mathrm{NO}_{\mathrm{x}}$ and $\mathrm{SO}_{2}$ concentrations over the entire dataset. Khalid et al. (2017) studied and examined energy consumption, environmental pollution, climate change, natural resources and $\mathrm{CO}_{2}$ emissions, greenhouse gas emissions in Pakistan. Delavar et al. (2019) determined the prediction models to determine air pollutions based on $\mathrm{PM}_{10}$ and $\mathrm{PM}_{2.5}$ pollution concentrations in Tehran. To predict the air-pollution, the data related to day of week, month of year, topography, meteorology, and pollutant rate of two nearest neighbors as the input parameters and machine learning methods were used. These methods include a regression support vector machine, geographically weighted regression, artificial neural network and autoregressive nonlinear neural network with an external input as the machine learning method for the air pollution prediction. Due to the negative impact of air pollution on human health, it is important to correctly forecast over-threshold events to give timely warnings to the population. Nonlinear models of the nonlinear autoregressive with exogenous variable (NARX) class have been extensively used to forecast air pollution time series, mainly using artificial neural networks to model the nonlinearities. Pisoni et al. (2009) discussed the possible advantages of using polynomial NARX instead, in combination with suitable model structure selection methods. Furthermore, a suitably weighted mean square error (MSE) (one-step-ahead prediction) cost function was used in the identification/learning process to enhance the model performance in peak estimation, which was the final purpose of this application. The proposed approach was applied to ground-level ozone concentration time series. An extended simulation analysis was provided to compare the two classes of models on a selected case study (Milan metropolitan area) and to investigate the effect of different weighting functions in the identification performance index. Sun et al. (2017) analysed the current published studies on the relationship between air pollution and food safety from the outlook of food organization. They observed agricultural emissions. These emissions substantially cause air pollution that could happen at every phase along the food supply chain.

In order to prevent air pollution and environmental problems, forecasting of the air 
quality has crucial role in air quality management systems (Aryal et al., 2013; Kusumaningtyas et al., 2018; Zheng et al., 2018). There are some conventional forecasting methods in the literature. This paper presents a new artificial neural network model unlike other studies. It uses a nonlinear autoregressive exogenous model (NARX) method. All air quality parameters are entered into the system for four different locations. Creation of this model provides obtaining and extracting of some unmeasured environmental parameters for other air quality stations. Missing data was forecasted with the created model. Training results were tested with current air quality data.

The organization of this study is as follows: Section 2 presents and shows air quality management systems and locations. Section 3 gives experimental measurements for four different locations. This section also realizes the proposed numerical method for forecasting air pollution parameters and details the numerical results. Results and discussion are given in Section 4. Finally, conclusions are provided in Section 5.

\section{Air Quality Management Systems and Locations}

It is known that the development of industry, increasing population and growth of cities cause air pollution. While air pollutants emitted from a local source show local effects, energy consumption, fossil fuel burning, increased motor vehicles cause deterioration of air quality in urban centers.

Çanakkale was selected as a model city. It is located in northwestern Turkey. Coordinate of Çanakkale is between $25^{\circ} 40^{\prime}-27^{\circ} 30^{\prime}$ east longitudes and $39 \circ 27 \quad$ '- $40^{\circ}{ }^{\circ} 45^{\prime}$ northern latitudes. It has an area of $9.887 \mathrm{~km}^{2}$. Air quality management system of Çanakkale can be followed up on the Internet (URL-2, 2019).

There are four air quality monitoring stations in Çanakkale. These are Çanakkale Merkez Station (since 2004), the districts of Çan (since 2012), Lapseki (since 2012), Biga (since 2010). Figure 1 shows air quality monitoring stations in Çanakkale-Turkey (URL-2, 2019).

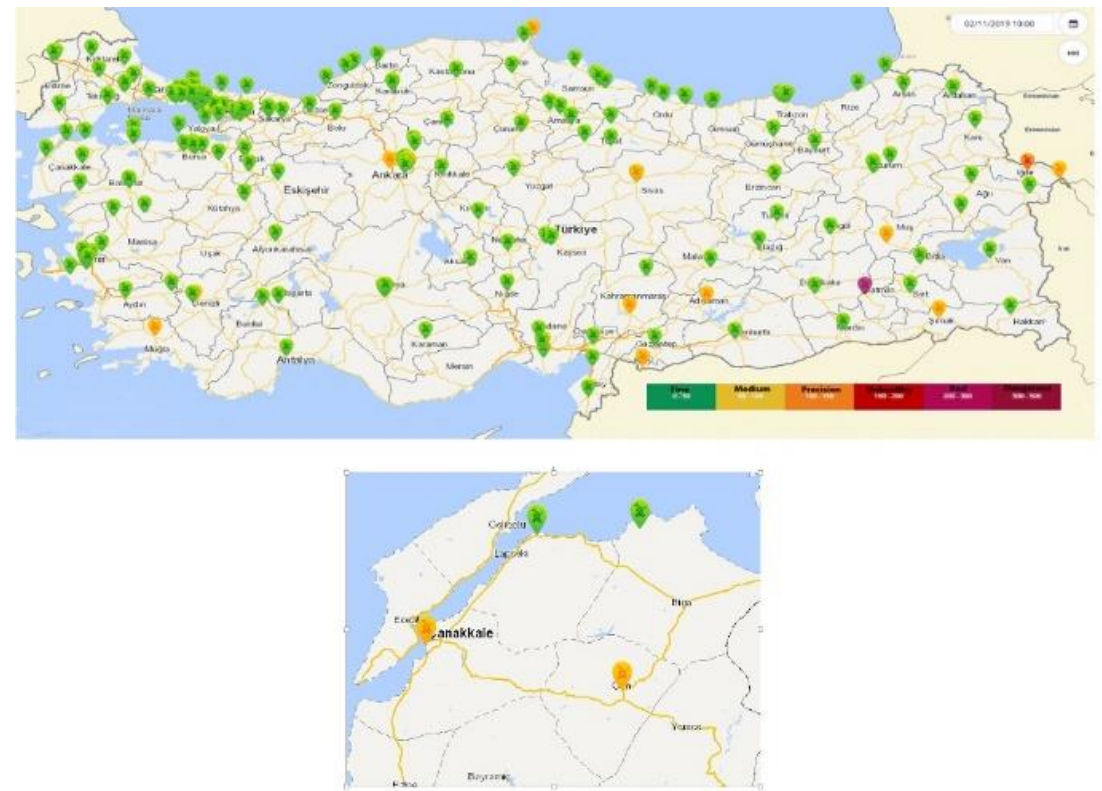

Figure 1. Air quality management system in Çanakkale-Turkey

Vehicular traffic and residential heating are the main sources of air pollution. These conditions should be taken into consideration when determining the city's air quality together with the adverse weather conditions caused by some meteorological events.

Sulfur oxide and particulate matter emissions have a high measurements at the fuel consumption used in heating. Especially during the winter season, fuels with unknown contents may adversely affect air pollution. However, natural gas is used for residential heating in Çanakkale city center and some districts. $\mathrm{SO}_{\mathrm{x}}$ and $\mathrm{PM}$ emissions are very low in usage of natural gas. But heavy traffic, concretion and the developing industry (mining companies, ceramic factories etc.) with increasing population have a significant impact on air pollution within Çanakkale. 
Foggy and unpleasant weather conditions are frequently observed in the various districts of Çanakkale, especially due to the use of solid fuels. In addition to these, thousands of ships crosses the Dardanelles Strait each year. It is known that a large number of ship passages significantly contribute to air pollution such as $\mathrm{SO}_{\mathrm{x}}$ and $\mathrm{NO}_{\mathrm{x}}$. This emission is increased especially in areas of inland seas and harbours. Their emissions tend to increase air pollution in the size of a global scale.

\section{Material and Method}

\subsection{Experimental Measurements}

Particulate matter (PM) is called particle pollution. The term for a mixture of solid particles and liquid droplets found in the air. Some particles, such as dust, dirt, soot, or smoke, are large or dark enough to be seen with the naked eye. Others are so small they can only be detected using an electron microscope. Particle pollution includes:

- $\mathrm{PM}_{10}$ - inhalable particles, with diameters that are generally 10 micrometers and smaller

- $\mathrm{PM}_{2.5}$ - fine inhalable particles, with diameters that are generally 2.5 micrometers and smaller

Sulfur dioxide $\left(\mathrm{SO}_{2}\right)$ is a gas. It is invisible and has a nasty, sharp smell. It reacts easily with other substances to form harmful compounds, such as sulfuric acid, sulfurous acid and sulfate particles. Sulfur dioxide affects human health when it is breathed in. It irritates the nose, throat, and airways to cause coughing, wheezing, shortness of breath, or a tight feeling around the chest.

Ozone $\left(\mathrm{O}_{3}\right)$ is a form of oxygen having the molecular form of $\mathrm{O}_{3}$. It is a bluish, unstable gas with a pungent odour, found in two parts of the atmosphere: the stratosphere and the troposphere.

Nitric oxide (NO), also called nitrogen monoxide, colourless toxic gas that is formed by the oxidation of nitrogen. Nitric oxide performs important chemical signaling functions in humans and other animals and has various applications in medicine. It has few industrial applications. It is a serious air pollutant generated by automotive engines and thermal power plants.

Nitrogen oxides (NOx) are poisonous gases derived from nitrogen and oxygen combustion under high pressure and temperatures. NOx is composed of nitric oxide (NO), and a smaller percentage of more poisonous nitrogen dioxide $\left(\mathrm{NO}_{2}\right)$. NOx has direct and indirect effects on human health. It can cause breathing problems, headaches, chronically reduced lung function, eye irritation, loss of appetite and corroded teeth. Indirectly, it can affect humans by damaging the ecosystems they rely on in water and on landharming animals and plants.

The Çanakkale air quality monitoring station measures parameters of $\mathrm{PM}_{10}$ and $\mathrm{SO}_{2}$. The Biga air quality monitoring station measures parameters of $\mathrm{PM}_{10}, \mathrm{SO}_{2}, \mathrm{NO}, \mathrm{NO}_{2}, \mathrm{NO}_{\mathrm{x}}$ and $\mathrm{O}_{3}$. The Çan air quality monitoring station measures parameters of $\mathrm{PM}_{10}, \mathrm{SO}_{2}, \mathrm{NO}, \mathrm{NO}_{2}, \mathrm{NO}_{\mathrm{x}}$ and $\mathrm{O}_{3}$. The Lapseki air quality monitoring station measures parameters of $\mathrm{PM}_{2.5}, \mathrm{SO}_{2}, \mathrm{NO}, \mathrm{NO}_{2}$, $\mathrm{NO}_{\mathrm{X}}$ and $\mathrm{O}_{3}$. In this study, the measurement data of these measurement stations between April 2013 and April 2018 was considered.

Figure 2 shows the alteration of the measured parameter of $\mathrm{SO}_{2}$ data between April 2013 and April 2018. It can be seen that especially, the measured parameter of $\mathrm{SO}_{2}$ is higher than others in Çan.

At the measurement station in Çanakkale Central, 1707 data were recorded among 1827 data for the daily average $\mathrm{SO}_{2}$. Measurements realized between April 2013 and April 2018. The daily average value of $\mathrm{SO}_{2}$ is measured as $11 \mu \mathrm{g} / \mathrm{m}^{3}$. The highest value is $68 \mu \mathrm{g} / \mathrm{m}^{3}$ on 1 December 2013 and the lowest value is $1 \mu \mathrm{g} / \mathrm{m}^{3}$ on 30 January 2014 . The calculated standard deviation is 10.

At the measurement station in Biga, 1622 data were recorded among 1827 data for the daily average $\mathrm{SO}_{2}$. Measurements realized between April 2013 and April 2018. The daily average value of $\mathrm{SO}_{2}$ is measured as $6 \mu \mathrm{g} / \mathrm{m}^{3}$. The highest value is $75 \mu \mathrm{g} / \mathrm{m}^{3}$ on 4 April 2018 and the lowest value is $0 \mu \mathrm{g} / \mathrm{m}^{3}$ on 5 July 2013 . The calculated standard deviation is 12.9 .

At the measurement station in Çan, 1739 data were recorded among 1827 data for the daily average $\mathrm{SO}_{2}$.

Measurements realized between April 2013 and April 2018. The daily average value of $\mathrm{SO}_{2}$ is measured as $76 \mu \mathrm{g} / \mathrm{m}^{3}$. The highest value is 917 $\mu \mathrm{g} / \mathrm{m}^{3}$ on 27 December 2013 and the lowest value is $0 \mu \mathrm{g} / \mathrm{m}^{3}$ on 28 July 2016 . The calculated standard deviation is 114.3 . 


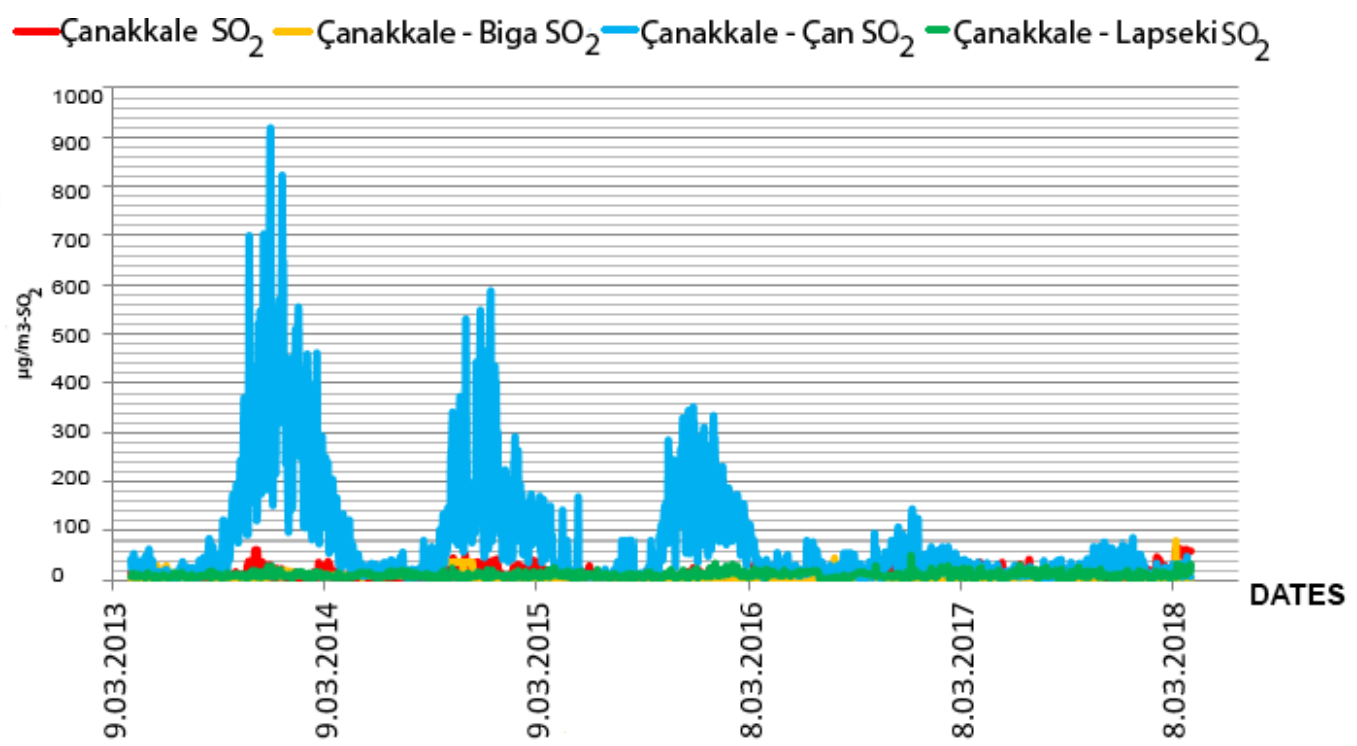

Figure 2. Alteration of the measured parameter of $\mathrm{SO}_{2}$ data between April 2013 and April 2018

At the measurement station in Lapseki, 1698 data were recorded among 1827 data for the daily average $\mathrm{SO}_{2}$. Measurements realized between April 2013 and April 2018. The daily average value of $\mathrm{SO}_{2}$ is measured as $9 \mu \mathrm{g} / \mathrm{m}^{3}$. The highest value is $49 \mu \mathrm{g} / \mathrm{m}^{3}$ on 2 January 2017 and the lowest value is $0 \mu \mathrm{g} / \mathrm{m}^{3}$ on 24 October 2015. The calculated standard deviation is 5.1 .

Figure 3 shows the measured parameter of PM at the four air quality monitoring stations. 1827 data are recorded.
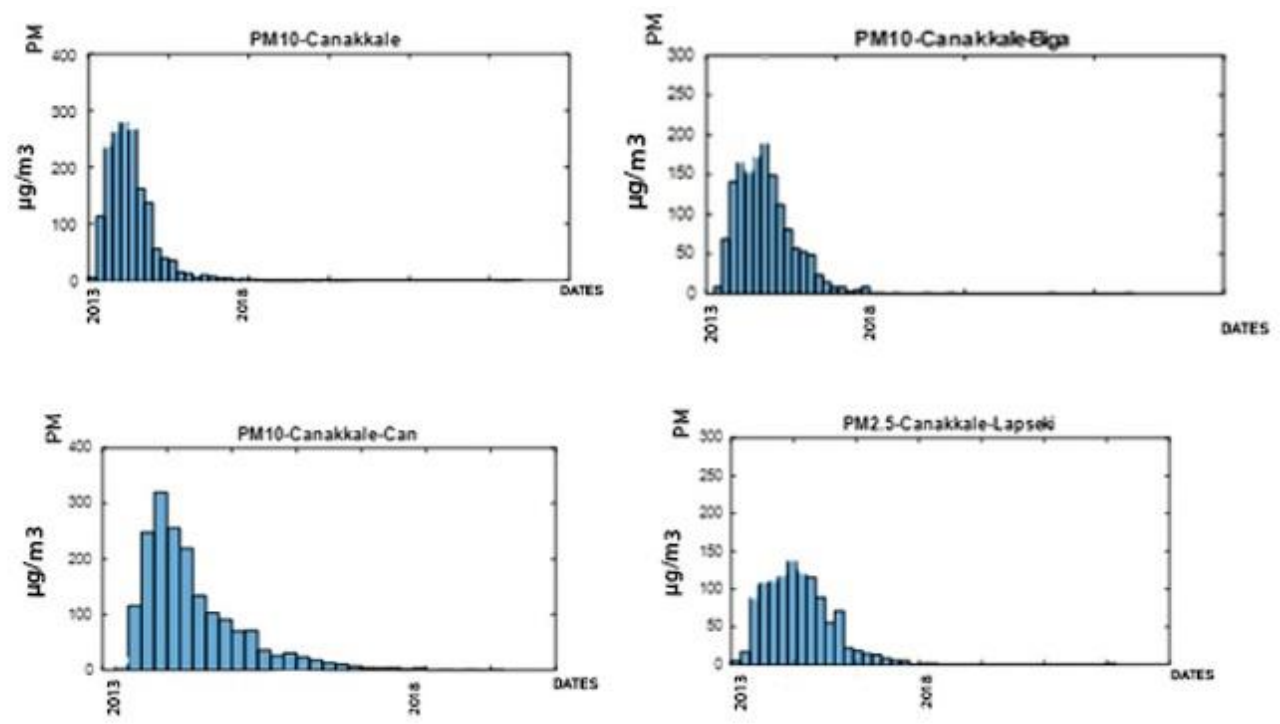

Figure 3. The measured parameter of PM at the four air quality monitoring stations

At the measurement station in Çanakkale Central, 1665 data were recorded among 1827 data for the daily average of $\mathrm{PM}_{10}$. Measurements realized between April 2013 and April 2018. The daily average value of $\mathrm{PM}_{10}$ is measured as $26 \mu \mathrm{g} / \mathrm{m}^{3}$. The highest value is $267 \mu \mathrm{g} / \mathrm{m}^{3}$ on 1 February 2015 and the lowest value is $3 \mu \mathrm{g} / \mathrm{m}^{3}$ on 4 October 2013. Calculated standard deviation is 15.8 .
At the measurement station in Biga, 1594 data were recorded among 1827 data for the daily average of $\mathrm{PM}_{10}$. Measurements realized between April 2013 and April 2018. The daily average value of $\mathrm{PM}_{10}$ is measured as $22 \mu \mathrm{g} / \mathrm{m}^{3}$. The highest value is $163 \mu \mathrm{g} / \mathrm{m}^{3}$ on 1 February 2015 and the lowest value is $5 \mu \mathrm{g} / \mathrm{m}^{3}$ on 5 July 2013 . The calculated standard deviation is 16 . 
At the measurement station in Çan, 1734 data were recorded among 1827 data for the daily average of $\mathrm{PM}_{10}$. Measurements realized between April 2013 and April 2018. The daily average value of $\mathrm{PM}_{10}$ is measured as $68 \mu \mathrm{g} / \mathrm{m}^{3}$. The highest value is $301 \mu \mathrm{g} / \mathrm{m}^{3}$ on 26 December 2013 and the lowest value is $11 \mu \mathrm{g} / \mathrm{m}^{3}$ on 2 October 2013. The calculated standard deviation is 38.8 .

At the measurement station in Lapseki, 1695 data were recorded among 1827 data for the daily average of $\mathrm{PM}_{2.5}$. Measurements realized between April 2013 and April 2018. The daily average value of $\mathrm{PM}_{2.5}$ is measured as $18 \mu \mathrm{g} / \mathrm{m}^{3}$. The highest value is $121 \mu \mathrm{g} / \mathrm{m}^{3}$ on 1 February 2015 and the lowest value is $0 \mu \mathrm{g} / \mathrm{m}^{3}$ on 26 December 2017. The calculated standard deviation is 9.4 .

Figure 4 introduces the measured parameter of $\mathrm{O}_{3}$ for the measurement station in the Çan and Biga.
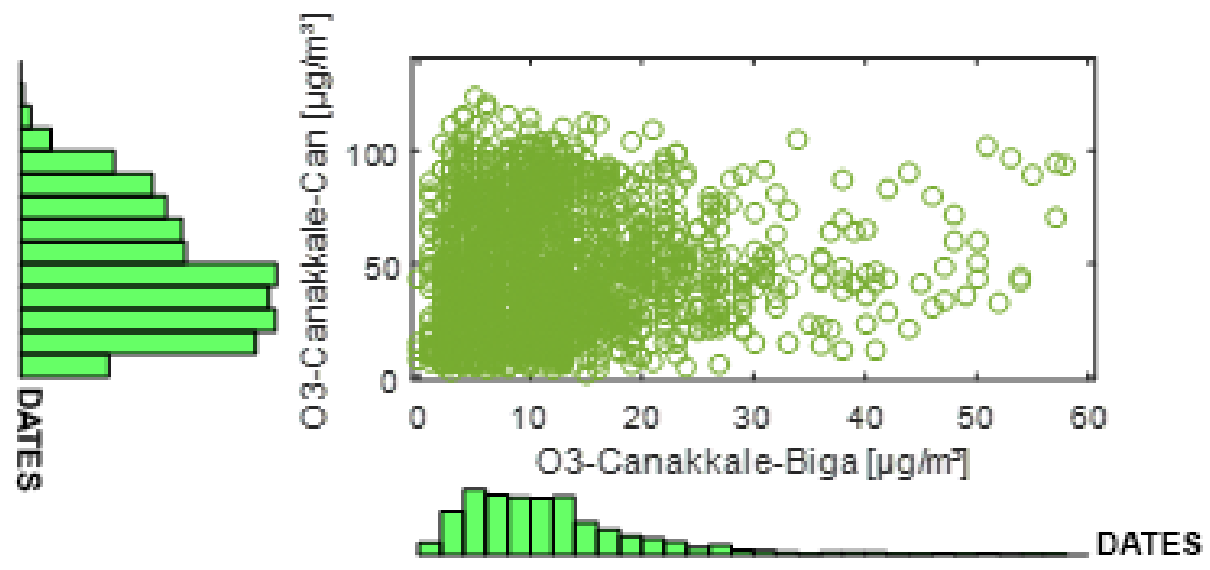

Figure 4. The measured parameter of $\mathrm{O}_{3}$ for the air quality monitoring stations of Çan and Biga

At the measurement station in Çan, 1753 data were recorded among 1827 data for the daily average of $\mathrm{O}_{3}$. Measurements realized between April 2013 and April 2018. Daily average value of $\mathrm{O}_{3}$ is measured as $47 \mu \mathrm{g} / \mathrm{m}^{3}$. The highest value is $124 \mu \mathrm{g} / \mathrm{m}^{3}$ on 25 June 2013 and the lowest value is $1 \mu \mathrm{g} / \mathrm{m}^{3}$ on 4 January 2017 . The calculated standard deviation is 26.8 .

At the measurement station in Biga, 1681 data were recorded among 1827 data for the daily average of $\mathrm{O}_{3}$. The measurements realized between April 2013 and 2018. The daily average value of $\mathrm{O}_{3}$ is measured as $66 \mu \mathrm{g} / \mathrm{m}^{3}$. The highest value is $128 \mu \mathrm{g} / \mathrm{m}^{3}$ on 10 August 2013 and the lowest value is $3 \mu \mathrm{g} / \mathrm{m}^{3}$ on 5 November 2016 . The calculated standard deviation is 24.1 .

Figure 5 presents the measured value of NO for the air quality monitoring stations of Çan, Biga and Lapseki.

At the measurement station in Biga, 1515 data were recorded among 1827 data for the daily average of NO. The measurements realized between April 2013 and April 2018. The daily average value of NO is measured as $6 \mu \mathrm{g} / \mathrm{m}^{3}$. The highest value is $212 \mu \mathrm{g} / \mathrm{m}^{3}$ on 7 November 2014 and the lowest value is $1 \mu \mathrm{g} / \mathrm{m}^{3}$ on 25 September 2014. The calculated standard deviation is 18.8 .

At the measurement station in Çan, 1389 data were recorded among 1827 data for the daily average of NO. The measurements realized between April 2013 and April 2018. The daily average value of NO is measured as $10 \mu \mathrm{g} / \mathrm{m}^{3}$. The highest value is $142 \mu \mathrm{g} / \mathrm{m}^{3}$ on 8 January 2018 and the lowest value is $0 \mu \mathrm{g} / \mathrm{m}^{3}$ on 6 June 2015 . The calculated standard deviation is 17 .

At the measurement station in Lapseki, 1475 data were recorded among 1827 data for the daily average of NO. Measurements realized between April 2013 and April 2018.

The daily average value of NO is measured as 1 $\mu \mathrm{g} / \mathrm{m}^{3}$. The highest value is $19 \mu \mathrm{g} / \mathrm{m}^{3}$ on 26 March 2015 and the lowest value is $0 \mu \mathrm{g} / \mathrm{m}^{3}$ on 13 May 2015. The calculated standard deviation is 2.5 .

Figure 6 shows the measured value of $\mathrm{NO}_{\mathrm{X}}$ for the air quality monitoring stations of Çan, Biga and Lapseki. 


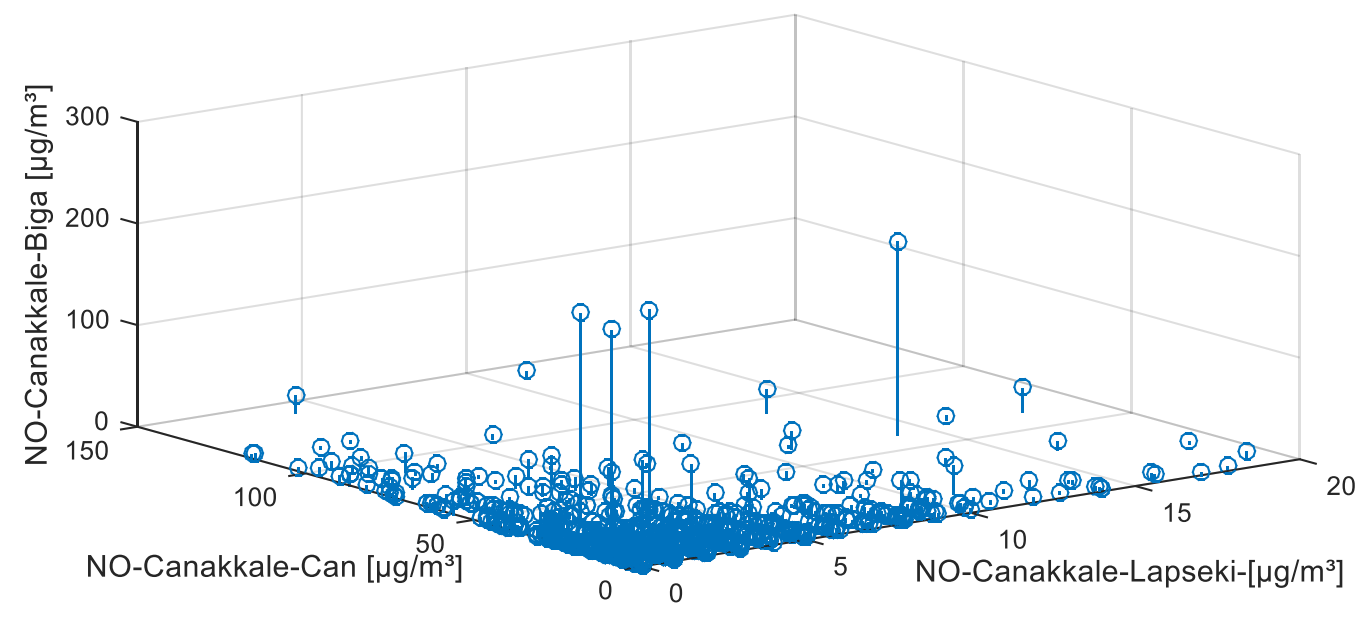

Figure 5. The measured value of NO for the air quality monitoring stations of Çan, Biga and Lapseki

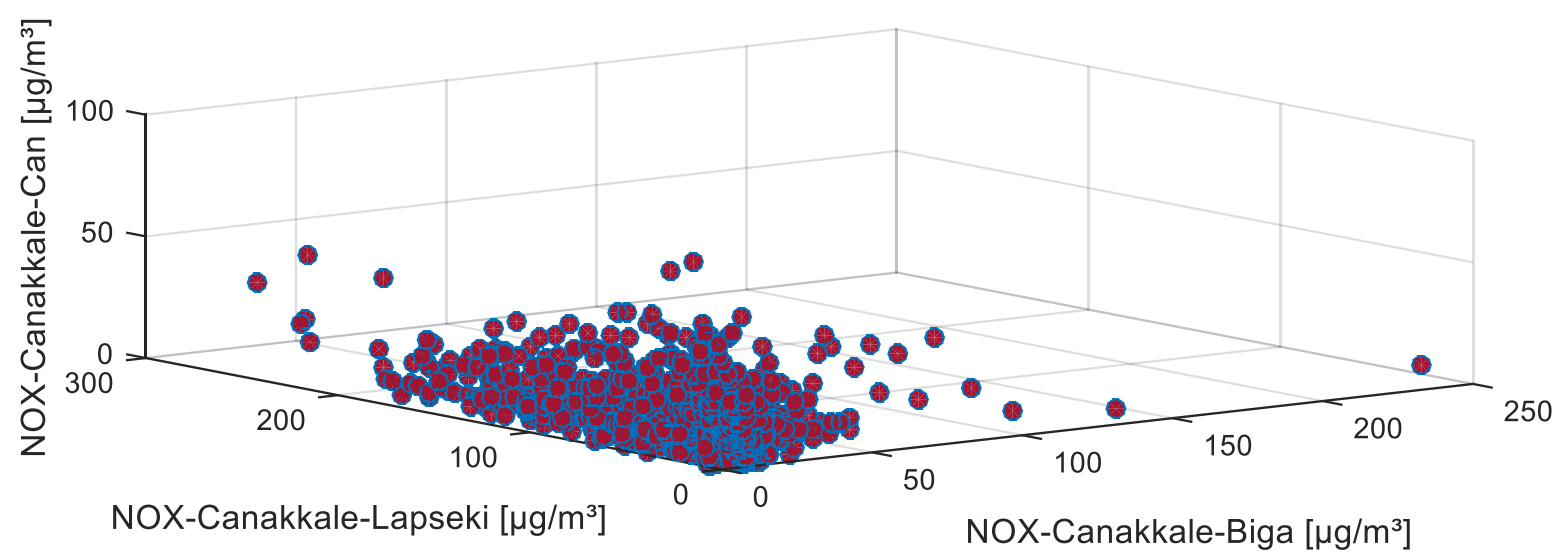

Figure 6. The measured value of $\mathrm{NO}_{\mathrm{X}}$ for the air quality monitoring stations of Çan, Biga and Lapseki

At the measurement station in Biga, 1515 data were recorded among 1827 data for the daily average of $\mathrm{NO}_{\mathrm{x}}$. The measurements realized between April 2013 and April 2018. The daily average value of $\mathrm{NO}_{\mathrm{X}}$ is measured as $13 \mu \mathrm{g} / \mathrm{m}^{3}$. The highest value is $240 \mu \mathrm{g} / \mathrm{m}^{3}$ on 14 July 2017 and the lowest value is $1 \mu \mathrm{g} / \mathrm{m}^{3}$ on 25 September 2014. The calculated standard deviation is 12.2.

At the measurement station in Çan, 1231 data were recorded among 1827 data for the daily average of $\mathrm{NO}_{\mathrm{x}}$. The measurements realized between April 2013 and April 2018. The daily average value of $\mathrm{NO}_{\mathrm{X}}$ is measured as $48 \mu \mathrm{g} / \mathrm{m}^{3}$. The highest value is $261 \mu \mathrm{g} / \mathrm{m}^{3}$ on 8 January 2018 and the lowest value is $1 \mu \mathrm{g} / \mathrm{m}^{3}$ on 13 August 2016. The calculated standard deviation is 41.6.
At the measurement station in Lapseki, 1456 data were recorded among 1827 data for the daily average of $\mathrm{NO}_{\mathrm{X}}$. The measurements realized between April 2013 and April 2018. The daily average value of $\mathrm{NO}_{\mathrm{X}}$ is measured as $11 \mu \mathrm{g} / \mathrm{m}^{3}$. The highest value is $79 \mu \mathrm{g} / \mathrm{m}^{3}$ on 6 April 2018 and the lowest value is $0 \mu \mathrm{g} / \mathrm{m}^{3}$ on 30 November 2016. The calculated standard deviation is 8.3.

\subsection{Numerical Method for Forecasting Air Pollution Parameters}

The hourly and daily data were used in the training of artificial neural networks. Matlab Neural network time series tool is used in order to solve this problem. NARX method is applied to the modeling system. The non-linear 
autoregressive network with exogenous inputs (NARX) is a recurrent dynamic network with feedback connections enclosing several layers of the network. The NARX model is based on the linear Autoregressive with Exogenous (ARX) model, which is commonly used in time-series modelling. The Çanakkale Central air quality monitoring station measures the parameters of $\mathrm{PM}_{10}$ and $\mathrm{SO}_{2}$. The Biga air quality monitoring station measures the parameters of $\mathrm{PM}_{10}, \mathrm{SO}_{2}$, $\mathrm{NO}, \mathrm{NO}_{2}, \mathrm{NO}_{\mathrm{X}}$ and $\mathrm{O}_{3}$. The Çan air quality monitoring station measures the parameters of $\mathrm{PM}_{10}, \mathrm{SO}_{2}, \mathrm{NO}, \mathrm{NO}_{2}, \mathrm{NO}_{\mathrm{x}}$ and $\mathrm{O}_{3}$. The Lapseki air quality monitoring station measures the parameters of $\mathrm{PM}_{2.5}, \mathrm{SO}_{2}, \mathrm{NO}, \mathrm{NO}_{2}, \mathrm{NO}_{\mathrm{X}}$ and $\mathrm{O}_{3}$. These data are trained by neural network and entered into the modeling system.

Parameters of $\mathrm{NO}, \mathrm{NO}_{2}, \mathrm{NO}_{\mathrm{X}}$ and $\mathrm{O}_{3}$ values are forecasted by a neural network. 1827 data were used for each data and the relationship between the parameters was tried to be established. Inputs of the proposed model are given in Table 1 and Figure 7. Also, Table 2 and Figure 8 give outputs of the proposed modeling system according to the inputs.

Table 1. Inputs of the proposed model

\begin{tabular}{|l|l|l|}
\hline & \multicolumn{2}{|c|}{ Inputs } \\
\hline 1 & $\mathrm{PM}_{10}$ & Çanakkale \\
\hline 2 & $\mathrm{PM}_{10}$ & Çanakkale - Biga \\
\hline 3 & $\mathrm{PM}_{10}$ & Çanakkale - Çan \\
\hline 4 & $\mathrm{PM}_{2.5}$ & Çanakkale - Lapseki \\
\hline 5 & $\mathrm{SO}_{2}$ & Çanakkale \\
\hline 6 & $\mathrm{SO}_{2}$ & Çanakkale - Biga \\
\hline 7 & $\mathrm{SO}_{2}$ & Çanakkale - Çan \\
\hline 8 & $\mathrm{SO}_{2}$ & Çanakkale - Lapseki \\
\hline
\end{tabular}

The NARX method is applied to the modeling system. The NARX Networks are similar to the training oriented Multilayer Layer Perceptron network architecture, but the network output is applied as input feedback. They are able to produce successful results in non-linear model simulations. These discrete-time systems are used as a mathematical model;
Table 2. Outputs of the proposed model

\begin{tabular}{|c|c|c|}
\hline & \multicolumn{2}{|r|}{ Outputs } \\
\hline 1 & $\mathrm{NO}$ & Çanakkale - Biga \\
\hline 2 & $\mathrm{NO}_{2}$ & Çanakkale - Biga \\
\hline 3 & $\mathrm{NO}_{\mathrm{x}}$ & Çanakkale - Biga \\
\hline 4 & $\mathrm{O}_{3}$ & Çanakkale - Biga \\
\hline 5 & $\mathrm{NO}$ & Çanakkale - Çan \\
\hline 6 & $\mathrm{NO}_{2}$ & Çanakkale - Çan \\
\hline 7 & $\mathrm{NO}_{\mathrm{X}}$ & Çanakkale - Çan \\
\hline 8 & $\mathrm{O}_{3}$ & Çanakkale - Çan \\
\hline 9 & $\mathrm{NO}$ & Çanakkale - Lapseki \\
\hline 10 & $\mathrm{NO}_{2}$ & Çanakkale - Lapseki \\
\hline 11 & $\mathrm{NO}_{\mathrm{X}}$ & Çanakkale - Lapseki \\
\hline 12 & $\mathrm{O}_{3}$ & Çanakkale - Lapseki \\
\hline 13 & $\mathrm{NO}$ & Çanakkale \\
\hline 14 & $\mathrm{NO}_{2}$ & Çanakkale \\
\hline 15 & $\mathrm{NO}_{\mathrm{X}}$ & Çanakkale \\
\hline 16 & $\mathrm{O}_{3}$ & Çanakkale \\
\hline
\end{tabular}

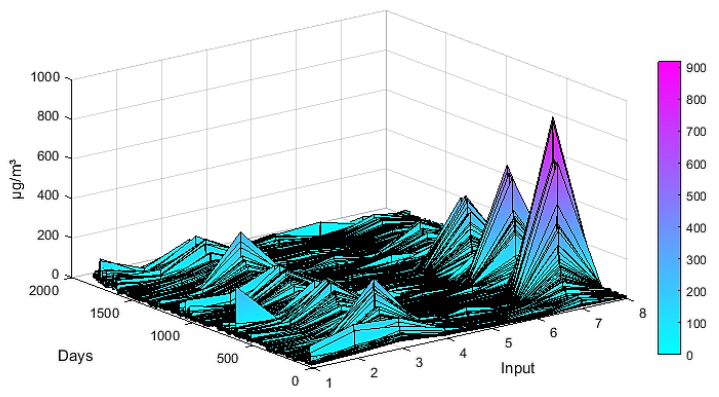

Figure 7. Inputs of the proposed model by the NARX method

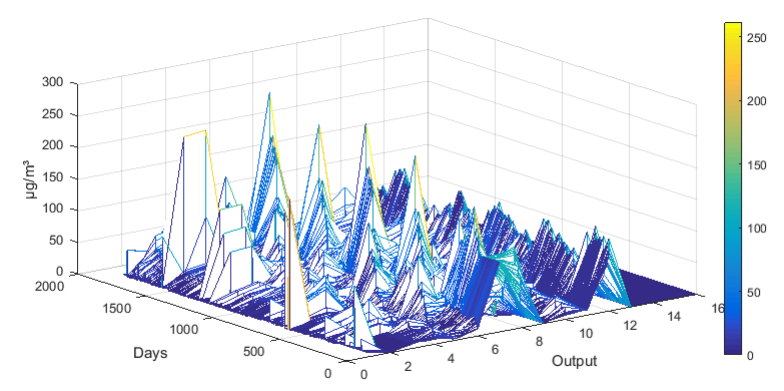

Figure 8. Outputs of the proposed model by the NARX method 
$o(t)=F(o(t-1), o(t-2), \ldots, o(t-k), x(t), x(t-1), \ldots, x(t-p))$

Here, $o(t-k) \in R$ and $x(t-p) \in R$ respectively denote the network outputs and inputs, $\mathrm{k}$ and $\mathrm{p}$ respectively denote the number of past outputs and past inputs to be applied for feedback, respectively. That is, the feedback and input layers are time-delayed and contain past data.

A used learning algorithm is called as the conjugate gradient backpropagation algorithm. Proposed this basic backpropagation algorithm regulates the weights in the steepest descent direction as the most negative of the gradient. Performance function of this direction is decreasing most quickly. It turns out that, although the function decreases most quickly along with the negative of the gradient, this does not necessarily produce the fastest convergence. In the conjugate gradient algorithms, a search is performed along such a direction. So, it produces generally faster convergence than the steepest descent direction, while conserving the error minimization achieved in all previous steps. This direction can be called as the conjugate direction. Generally, the step-size of these algorithms is adjusted for the each iteration. A search is made along the conjugate gradient direction to determine the step size. This situation provides minimizing the performance function along that line. All of these algorithms start out by searching in the steepest descent direction at the first iteration.

In order to realize the proposed modeling system, we used neural network time series. It solves problems of dynamic neural network. Figure 9 shows the cellular structure of the model created by the NARX method.

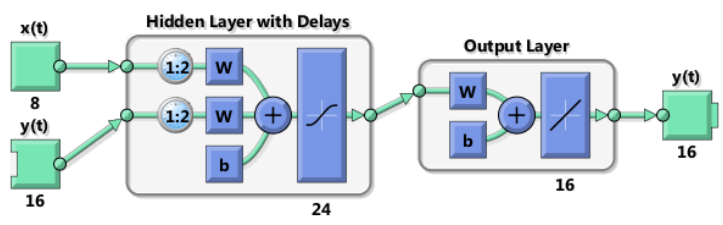

Figure 9. The cellular structure of the model created by the NARX method

The parameters of $\mathrm{PM}_{10}$ and $\mathrm{SO}_{2}$ are modeled as inputs of the NARX and $\mathrm{NO}, \mathrm{NO}_{2}, \mathrm{NO}_{\mathrm{X}}$ and $\mathrm{O}_{3}$ data are modeled as outputs of the NARX, respectively. Data of the four air quality measurement system are used for this proposed model. This method has also closed loop in order to reach the best performance.

The network was trained with 1827 data for each of the 14 parameters measured at the four measurement stations. The entrance number of the network is 8 , the number of neurons is 24 in the hidden layer, and the number of neurons is 16 in the output layer. The training algorithm is called as the conjugate gradient backpropagation algorithm. Figure 10 presents the best validation performance. Also, figure 11 shows the error histogram.

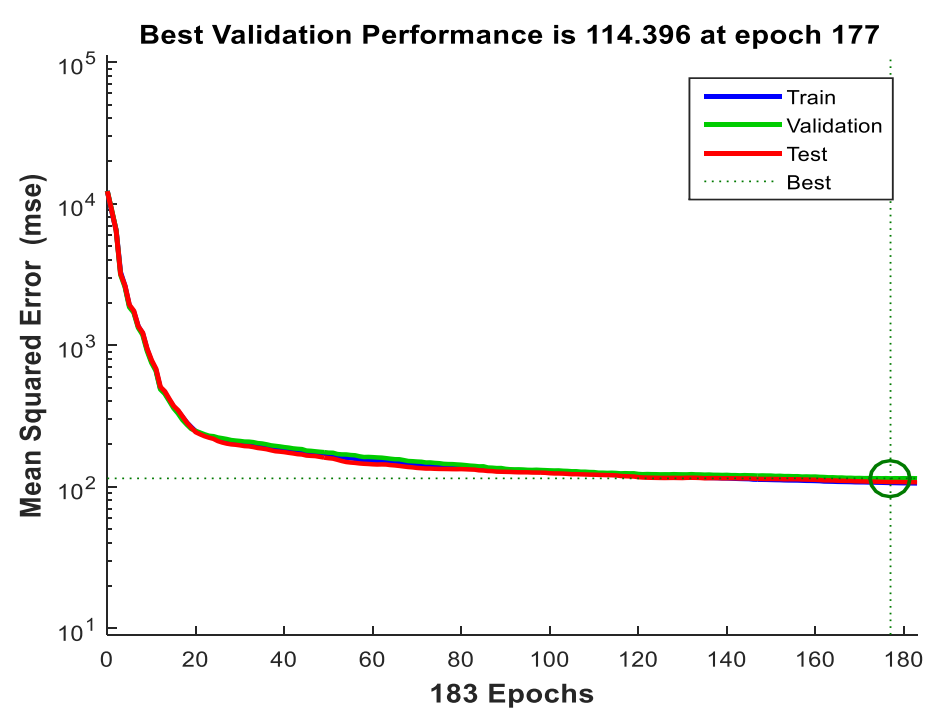

Figure 10. Best validation performance for the proposed model 
In figure 10, the mean (average) magnitude of the squares of the error: the distance between the model's estimate of test values and the actual test value. Generally, the error reduces after more epochs of training, but might start to increase on the validation data set as the network starts overfitting the training data. In the default setup, the training stops after consecutive increases in validation error, and the best performance is taken from the epoch with the lowest validation error.

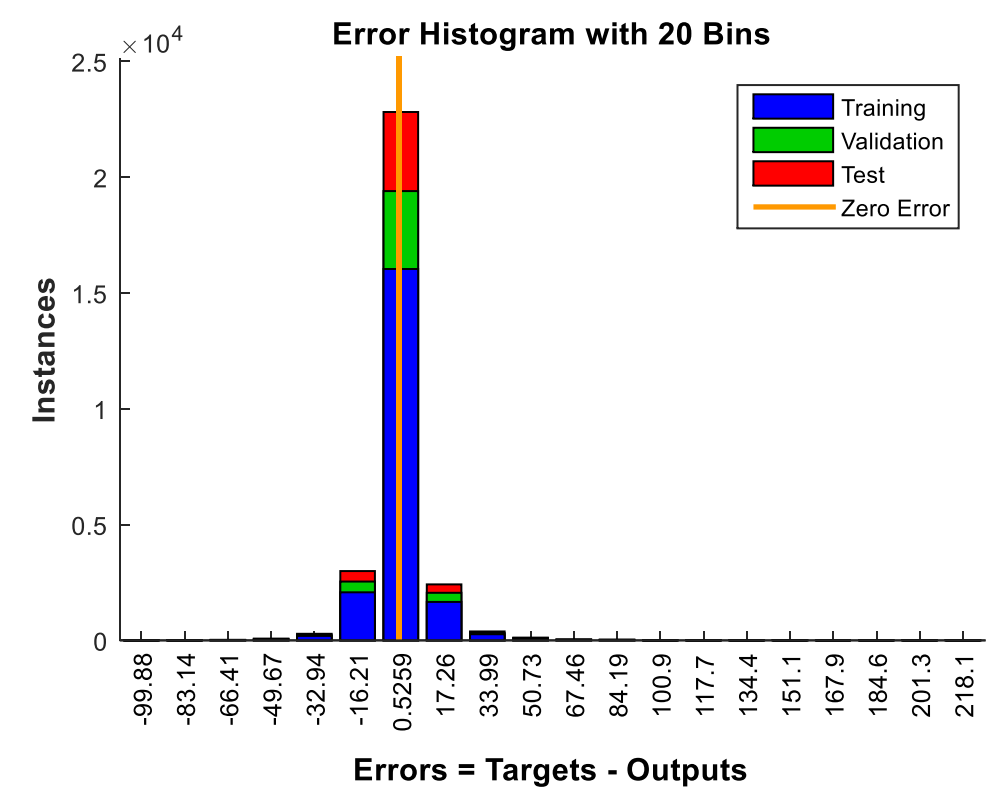

Figure 11. The error histogram

The figure 11 highlights the fact that the majority of the errors falls between -16.21 and 17.26, a narrow interval, and only for a very few training points, the errors fall outside this range (most of the errors being around the 0.5259 value). Therefore, the error histogram highlights the fact that the devised method has output results with a very good forecasting accuracy.

For this algorithm, results are repeatedly trained. The best result has been investigated by changing the number of layers and the network inputs and outputs in the hidden layer. The learning process is realized as 8 inputs and 16 outputs. Also, the success of the earning process is over $90 \%$. Figure 12 shows the learning process results. Also, Figure 13-15 introduces error correlations. The error values are minimized in order to achieve the learning process.

Figure 12 shows the correlation between the target and output values for both the training and validation, created in MATLAB software. According to this figure, both the training and validation show desirable correlation coefficients ( $\mathrm{R}$ values). The correlation coefficient shows how strong the association between two variables are.
The figure 13 of input-error cross-correlation function illustrates how the errors are correlated with the input sequence $x(t)$. For a perfect prediction model, all of the correlations should be zero. If the input is correlated with the error, then it should be possible to improve the prediction, perhaps by increasing the number of delays in the tapped delay lines. In this case, all of the correlations fall within the confidence bounds around zero.

The figure 14 displays the error autocorrelation function. It describes how the prediction errors are related in time. For a perfect prediction model, there should only be one nonzero value of the autocorrelation function, and it should occur at zero lag. This would mean that the prediction errors were completely uncorrelated with each other. If there was significant correlation in the prediction errors, then it should be possible to improve the prediction - perhaps by increasing the number of delays in the tapped delay lines. In this case, the correlations, except for the one at zero lag, fall approximately within the $90 \%$ confidence limits around zero, so the model seems to be adequate. 

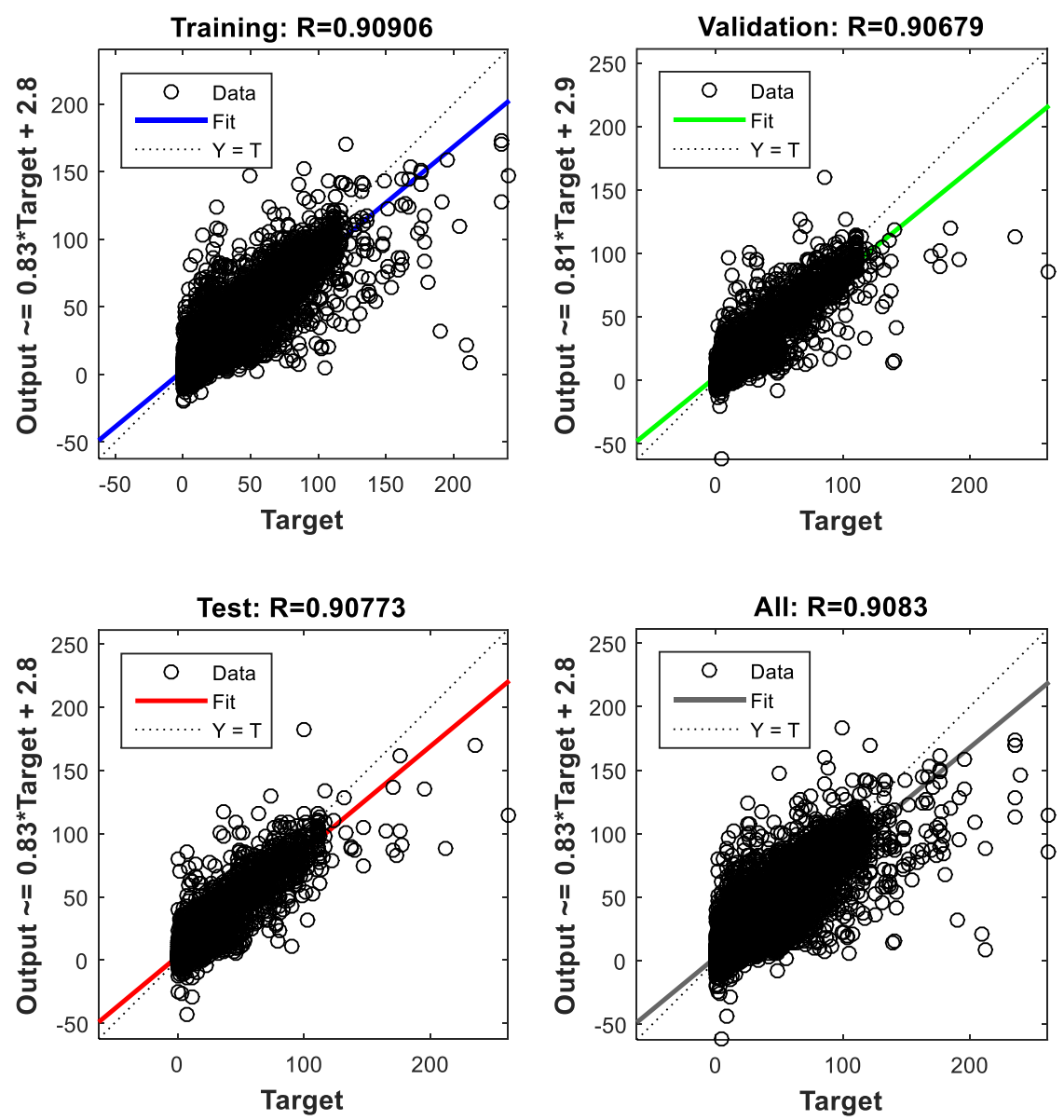

Figure 12. The conjugate gradient backpropagation algorithm learning process results

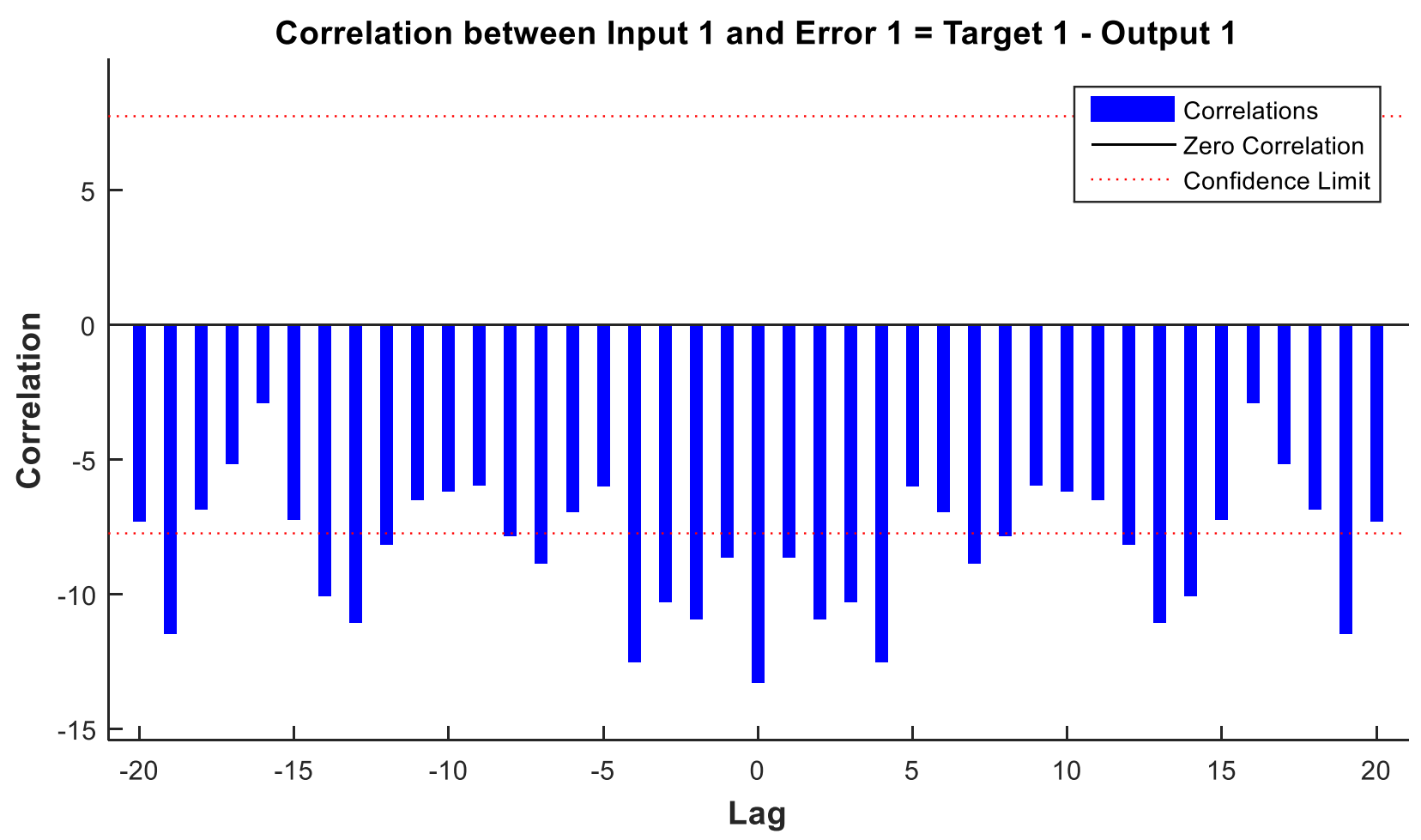

Figure 13. The correlation between input 1 and error 1 


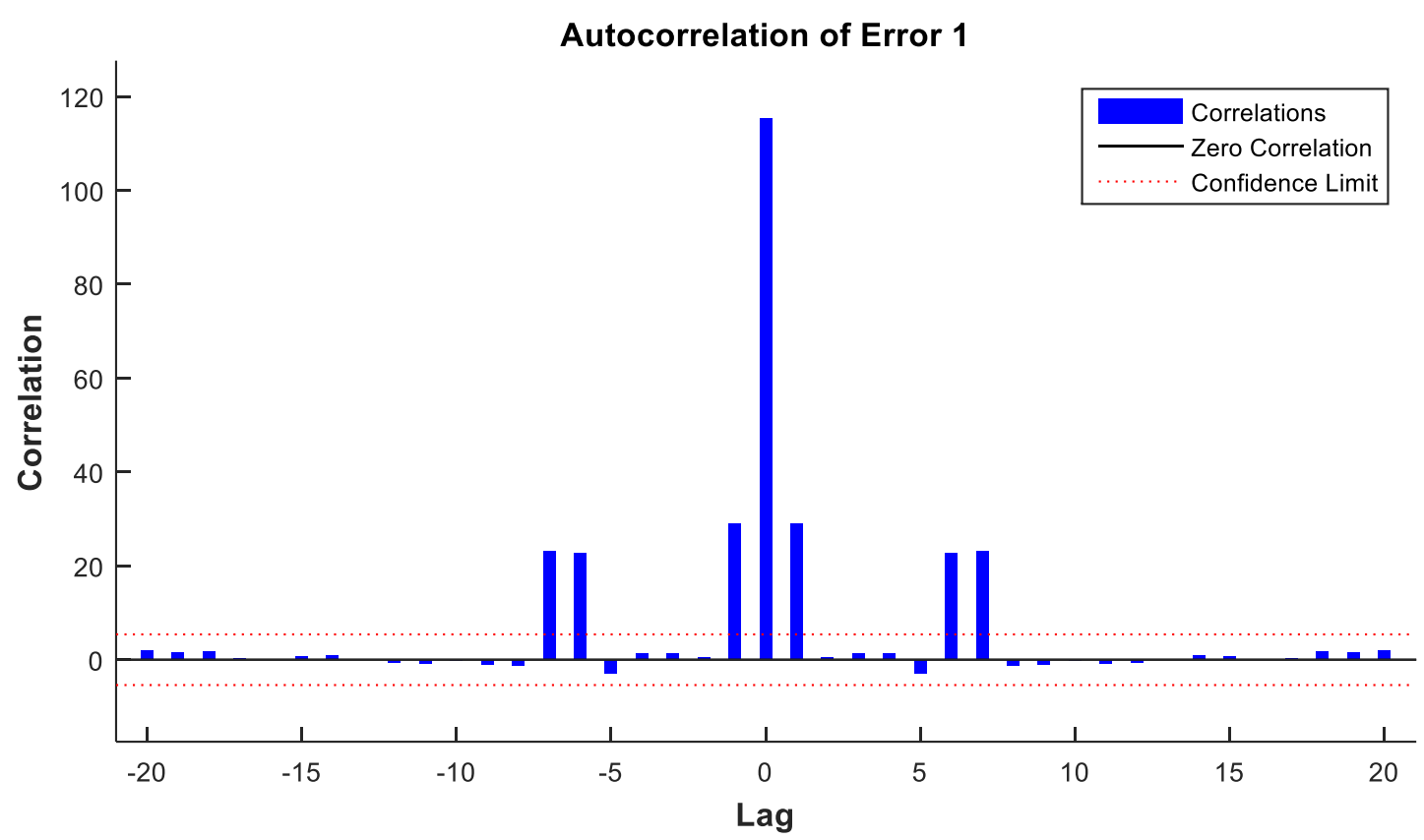

Figure 14. Autocorrelation of error 1

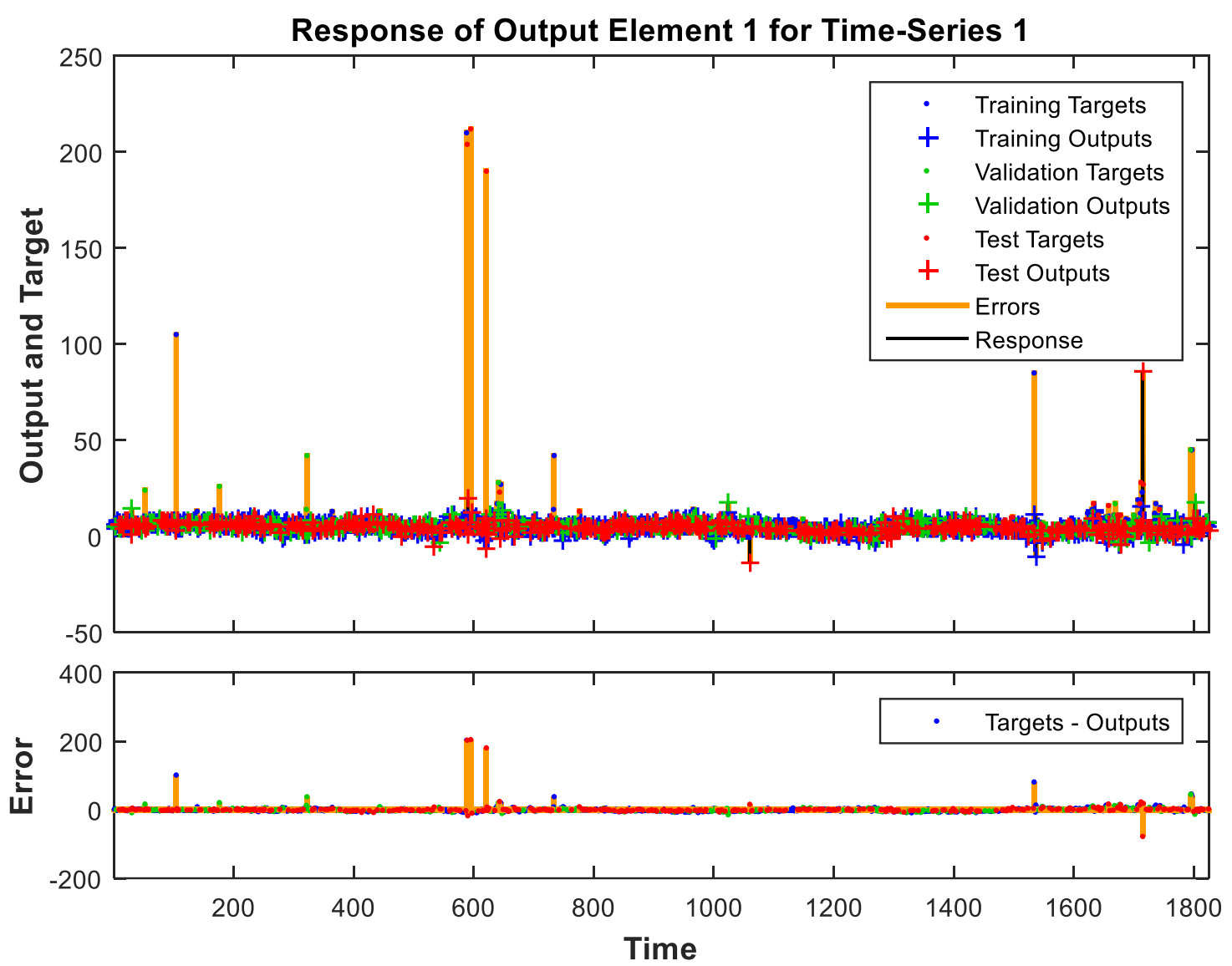

Figure 15. The response of output element 1 for time-series 1

The figure 15 displays the inputs, targets and errors versus time. It also indicates which time points were selected for training, testing and validation. Proposed model by the NARX method is applied to the system. The obtained parameters of $\mathrm{NO}, \mathrm{NO}_{2}, \mathrm{NO}_{\mathrm{x}}$ and $\mathrm{O}_{3}$ are forecasted for Çanakkale Central. Successful results are obtained by minimized errors as shown in Figure 16. 


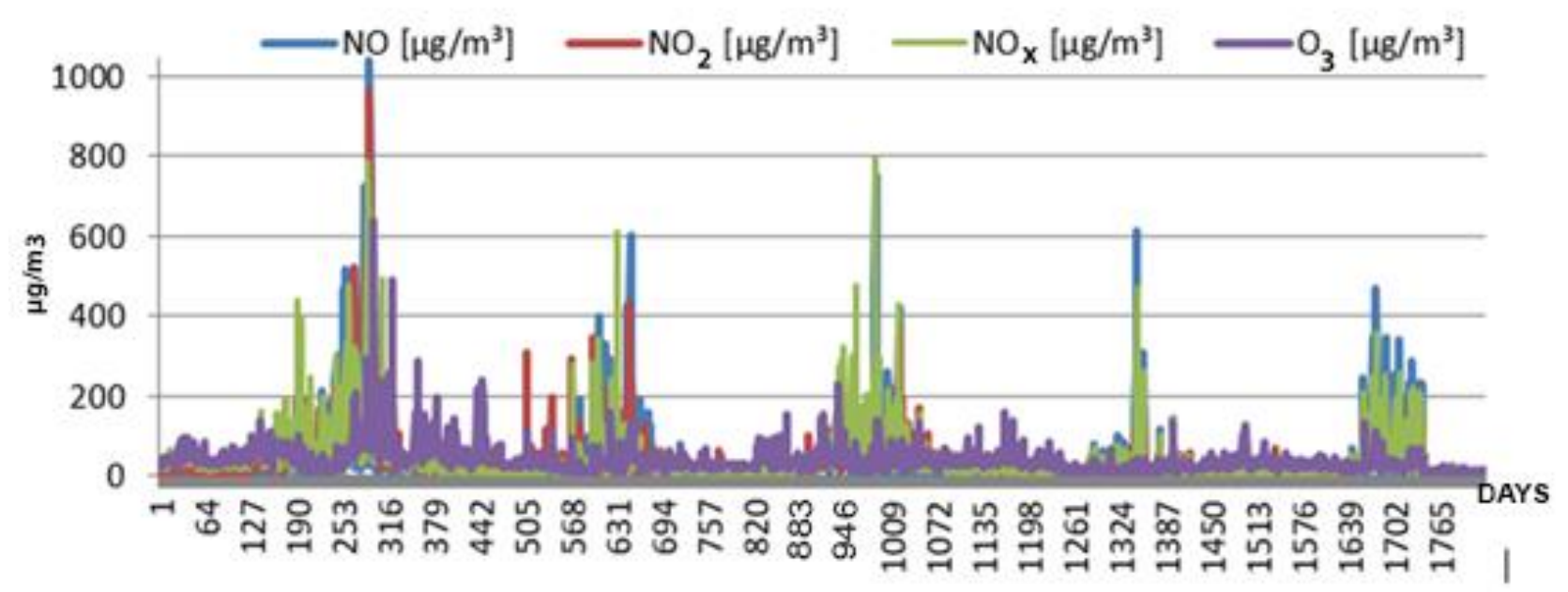

Figure 16. Successful results for obtained parameters of $\mathrm{NO}, \mathrm{NO}_{2}, \mathrm{NO}_{\mathrm{X}}$ and $\mathrm{O}_{3}$ in Çanakkale Central

\section{Results and Discussion}

As seen in figure 16, numerical results are realized for Çanakkale Central. The measurement data between April 2013 and April 2018 was considered. Table 3 shows the results with statistical tool.

Table 3. The results with statistical tool

\begin{tabular}{|c|c|c|c|}
\hline $\begin{array}{c}\text { Pollutants } \\
\text { Parameters }\end{array}$ & $\begin{array}{c}\text { Max } \\
\text { Value } \\
\left(\boldsymbol{\mu g} / \mathbf{m}^{3}\right)\end{array}$ & $\begin{array}{c}\text { Min } \\
\text { Value } \\
\left(\boldsymbol{\mu g} / \mathbf{m}^{3}\right)\end{array}$ & $\begin{array}{c}\text { Avg } \\
\text { Value } \\
\left(\boldsymbol{\mu g} / \mathbf{m}^{3}\right)\end{array}$ \\
\hline $\mathrm{NO}$ & 1042.074 & 0.25 & 32 \\
\hline $\mathrm{NO}_{2}$ & 958.62 & 1.18 & 37 \\
\hline $\mathrm{NO}_{\mathrm{x}}$ & 795.39 & 0.67 & 40 \\
\hline $\mathrm{O}_{3}$ & 636.74 & 2.96 & 40 \\
\hline
\end{tabular}

These results show that the lowest parameter of NO value is obtained as $0.25 \mu \mathrm{g} / \mathrm{m}^{3}$ while the highest value is obtained as $1042.074 \mu \mathrm{g} / \mathrm{m}^{3}$. Also, the average NO is found as $32 \mu \mathrm{g} / \mathrm{m}^{3}$. The lowest parameter of $\mathrm{NO}_{2}$ value is obtained as $1.18 \mu \mathrm{g} / \mathrm{m}^{3}$ while the highest value is obtained as 958.62 $\mu \mathrm{g} / \mathrm{m}^{3}$. Also, the average $\mathrm{NO}_{2}$ is found as 37 $\mu \mathrm{g} / \mathrm{m}^{3}$. The lowest parameter of the $\mathrm{NO}_{\mathrm{X}}$ value is obtained as $0.67 \mu \mathrm{g} / \mathrm{m}^{3}$ while the highest value is obtained as $795.39 \mu \mathrm{g} / \mathrm{m}^{3}$. Also, the average $\mathrm{NO}_{\mathrm{X}}$ is found as $40 \mu \mathrm{g} / \mathrm{m}^{3}$. The lowest parameter of the $\mathrm{O}_{3}$ value is obtained as $2.96 \mu \mathrm{g} / \mathrm{m}^{3}$ while the highest value is obtained as $636.74 \mu \mathrm{g} / \mathrm{m}^{3}$. Also, the average $\mathrm{O}_{3}$ is found as $40 \mu \mathrm{g} / \mathrm{m}^{3}$. These results show that the obtained forecasted parameter values are very successful and error acceleration is very low. This realized model can be used in the desired locations.

\section{Conclusions}

In this study, four different locations have been selected. These are Çanakkale Central and the districts of Çan, Lapseki and Biga. Measurements were carried out between April 2013 and April 2018. The daily air quality parameters were measured and recorded for these stations. Within these stations, the Çanakkale Central air quality monitoring station measured only $\mathrm{PM}_{10}$ and $\mathrm{SO}_{2}$ parameters while others measured the parameters of $\mathrm{PM}_{10}, \mathrm{PM}_{2.5}, \mathrm{SO}_{2}, \mathrm{NO}, \mathrm{NO}_{2}, \mathrm{NO}_{\mathrm{x}}$ and $\mathrm{O}_{3}$. In order to forecast the unmeasured air quality parameters, a NARX model was created. The success of the learning process is over $90 \%$. In the time series modeling, a non-linear autoregressive exogenous model (NARX) is a nonlinear autoregressive model which has exogenous inputs. All measured parameters are defined as the input for this proposed system. Then this mathematical model is applied to the system. This provides forecasting of other air quality parameters and a comparison between numerical and measurement results.

\section{References}

Aryal, R., Kafley, D., Beecham, S. and Morawska, L., 2013. Air Quality in the Sydney Metropolitan Region during the 2013 Blue Mountains Wildfire. Aerosol and Air Quality Research. 18 (9), 2420-2432.

doi: 10.4209/aaqr.2017.10.0427.

Delavar, M., Gholami, A., Shiran, G., Rashidi, Y., Nakhaeizadeh, G., Fedra, K. and Afshar, S. H., 2019. A Novel Method for Improving Air Pollution Prediction Based on Machine Learning Approaches: A Case Study Applied to the Capital City of Tehran. International Journal 
of Geo -Information. 8(2), 99, 1-20. doi: 10.3390/ijgi8020099.

Fathy El-Sharkawy, M. and Javed, W., 2018. Study of Indoor Air Quality Level in Various Restaurants in Saudi Arabia. Environment Progress \& Sustainable Energy. 37(5), 1713-1721. doi: 10.1002/ep. 12859.

Hamaoui-Laguel, L., Meleux, F., Beekmann, M., Bessagnet, B., Génermont, S., Cellier, P. and Létinois, L., 2014. Improving Ammonia Emissions in Air Quality Modelling for France. Atmospheric Environment. 92, 584-595. doi: 10.1016/j.atmosenv.2012.08.002.

Hristov, A. N., 2011. Contribution of Ammonia Emitted from Livestock To Atmospheric Fine Particulate Matter (PM 2.5) in the United States. Journal of Dairy Science. 94 (6), 3130-3136. doi: $10.3168 /$ jds.2010-3681.

Hung, C-H., Lo, K-C. and Yuan, C-S., 2018. Forming Highly Polluted PMs Caused by the Invasion of Transboundary Air Pollutants: Model Simulation and Discussion. Aerosol and Air Quality Research. 18 (7), 1698-1719. doi: 10.4209/aaqr.2017.11.0488.

Khalid, Z., Iqra, A. and Muneeb A., 2017. Decomposing The Linkages Between Energy Consumption, Air Pollution, Climate Change and Natural Resource Depletion in Pakistan. Environmental Progress \& Sustainable Energy. 36 (2), 638-648. doi: 10.1002/ep.12519.

Kurt, A. and Oktay, A. B., 2010. Forecasting Air Pollutant Indicator Levels with Geographic Models 3 Days in Advance Using Neural Networks. Expert Systems with Applications. 37 (12), 7986-7992. doi: 10.1016/j.eswa.2010.05.093.

Jaikumar, R., Nagendra, S. M. S. and Sivanandan, R., 2018. Development of NARX Based Neural Network Model for Predicting Air Quality Near Busy Urban Corridors, In: Zadeh, L. A., Yaser, R.R., Shahbazova, S. N., Reformat, M. Z. and Kreinovich, V. (Eds.), Recent Developments and the New Direction in Soft-Computing Foundations and Applications, Springer International Publishing, 581-593.

Kusumaningtyas, S., Aldrian, E., Wati, T. and Atmoko, D., 2018. The Recent State of Ambient Air Quality in Jakarta. Aerosol and Air Quality Research. 18 (4), 2343-2354. doi: 10.4209/aaqr.2017.10.0391.

Mickelson, A. and Tsvankin, D., 2017. Water Quality Monitoring for Coupled Food, Energy and Water Systems. Environment Progress \& Sustainable Energy. 37 (1), 165-171. doi: doi.org/10.1002/ep.12789.
Ortiz-Garcia, E. G., Salcedo-Sanz, S., Perez-Bellido, A. M., Portilla-Figueras, J. A. and Prieto, L., 2010. Prediction of Hourly O3 Concentrations Using Support Vector Regression Algorithms. Atmospheric Environment. 35 (44), 4481-4488. doi: 10.1016/j.atmosenv.2010.07.024.

Pisoni, E., Fariha, M., Carnevale, C. and Piroddi, L., 2009. Forecasting Peak Air Pollution Levels Using NARX models. Engineering Applications of Artificial Intelligence. 22(4-5), 593-602. doi: 10.1016/j.engappai.2009.04.002.

Sheppard, S. C., Bittman, S. and Bruulsema, T. W., 2010. Monthly Ammonia Emissions from Fertilizers In 12 Çanadian Ecoregions. Çanadian Journal of Soil Science. 90(1), 113-127. doi: 10.4141/CJSS09006.

Sun, F., Yun, D. and Yu, X., 2017. Air Pollution, Food Production and Food Security: A Review from The Perspective of Food System. Journal of Integrative Agriculture. 16 (12): 2945-2962. doi: 10.1016/S2095-3119(17)61814-8.

URL-1,https://www.unece.org/environmentalpolicy/conventions/envlrtapwelcome/crosssectoral-linkages/air-pollution-and-foodproduction.html. May 1, 2018.

URL-2, www.havaizleme.gov.tr. November 2, 2019.

URL-3, https://www.canakkalekalem.com/biga-zehirsoluyor/. November 8, 2019.

Wang, D., Wei, S., Luo, H., Yue, C. and Grunder, O., 2017. A Novel Hybrid Model for Air Quality Index Forecasting Based on Two-Phase Decomposition Technique and Modified Extreme Learning Machine. Science of the Total Environment. 580, 719-733. doi: 10.1016/j.scitotenv.2016.12.018.

Wilkinson, S., Mills, G., Illidge, R. and Davies, W. J., 2012. How is Ozone Pollution Reducing Our Food Supply? Journal of Experimental Botany. 63(2), 527-536. doi: 10.1093/jxb/err317.

Zheng, H., Liu, J., Tang, X., Wang, Z., Wu, H., Yan, P. and Wang, W., 2018. Improvement of the Realtime PM2.5 Forecast over the Beijing-TianjinHebei Region using an Optimal Interpolation Data Assimilation Method. Aerosol and Air Quality Research. 18 (5): 1305-1316. doi: 10.4209/aaqr.2017.11.0522.

Zhu, S., Lian, X., Liu, H., Hu, J., Wang, Y. and Che, J., 2017. Daily Air Quality Index Forecasting with Hybrid Models: A Case in China. Environmental Pollution. 231 (Pt 2), 1232-1244. doi: 10.1016/j.envpol.2017.08.069. 